
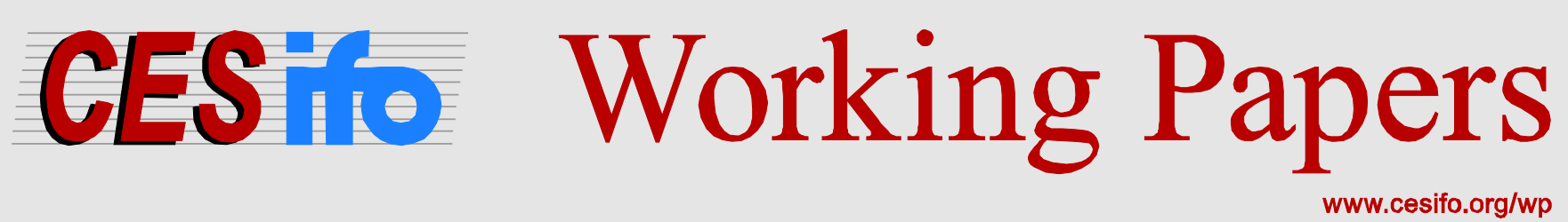

\title{
Tax vs. Regulation Policy and the Location of Financial Sector FDI
}

\author{
Julia Merz \\ Michael Overesch \\ Georg Wamser
}

CESIFO WORKING PAPER NO. 5500

CATEGORY 1: PUBLIC FinANCE

SEPTEMBER 2015

An electronic version of the paper may be downloaded

- from the SSRN website:

- from the RePEc website:

- from the CESifo website:

WWW.SSRN.com

www.RePEc.org

www.CESifo-group.org/wp 


\title{
Tax vs. Regulation Policy and the Location of Financial Sector FDI
}

\begin{abstract}
This paper analyzes how corporate taxation and regulatory requirements affect the location of financial sector FDI. We use novel information on new financial services entities established by multinational firms in 83 host countries. We find a negative effect of host country taxes on the probability of choosing a particular host location. We can also confirm a significant influence of the regulatory environment. For example, stricter (equity) capital requirements negatively affect location probabilities. Our empirical approach allows us to provide new insight in how a policy measure of a given country affects other countries by estimating cross-country tax and regulation elasticities.
\end{abstract}

JEL-Code: F300, G210, G280, H870.

Keywords: financial sector taxation, multinational banks, corporate taxation, mixed logit model.

Julia Merz
University of Cologne
Albertus-Magnus-Platz
Germany - 50923 Cologne
merz@wiso.uni-koeln.de

Georg Wamser

University of Tübingen

Mohlstraße 36

Germany - 72074 Tübingen

georg.wamser@uni-tuebingen.de
Michael Overesch

University of Cologne

Albertus-Magnus-Platz

Germany-50923 Cologne

overesch@wiso.uni-koeln.de 


\section{Introduction}

Foreign direct investment (FDI) of the financial sector has substantially increased during the last decades. For example, the share of foreign owned banks jumped from $20 \%$ in 1995 to $34 \%$ in $2009 .{ }^{1}$ The emergence of global banks is closely related to the emergence of multinational companies (MNCs) whose international operations require services like lending, currency or cash management. Particularly after the recent financial crisis many countries have seen a need to restrict banks' international activities. More and more global banks, on the other hand, express their concerns about excessive compliance costs associated with stricter regulation. Some of them even reconsider their international strategies as the costs of being global seem to exceed the benefits thereof (see the Economist, Global banks, A world of pain, March $7^{\text {th }}, 2015$, p. 59-61).

The revelations about the so-called "Luxembourg leaks" drew even more attention to international banking and tax issues. ${ }^{2}$ Several banks were involved in complex cross-border lending structures set up to avoid taxes and benefit from Luxembourg's many tax exemptions. In addition, some banks supported their clients in tax evasion through Luxembourg-based subsidiaries. ${ }^{3}$ All this has led legislators of many countries to impose new and stricter regulations. For example, under the US Foreign Account Tax Compliance Act (FATCA) passed in 2010, financial institutions all over the world are supposed to exchange information on American clients vis à vis the US Internal Revenue Service (IRS) to make it more difficult for tax dodgers to hide money abroad. Another example is the OECD's (2013) action plan against base erosion and profit shifting (BEPS).

\footnotetext{
${ }^{1}$ This information is taken from Claessen and Van Horen (2012) and based on 137 countries.

${ }^{2}$ Among other reports, Financial Times, November 6 ${ }^{\text {th }}, 2014$, http://www.ft.com/intl-/cms/s/0/c8de6734-65d011e4-898f-00144feabdc0.html\#axzz3UCJyeIKz.

${ }^{3}$ For example, the German Commerzbank AG, cf. Financial Times February $24^{\text {th }} 2015$, http://www.ft.com/intl/cms/s/0/dac3b366-bc5e-11e4-a6d7-00144feab7de.html\#axzz3Udg5CrZF.
} 
Although there is broad agreement that policy action is needed, it is not clear which policy measures are the most effective ones or whether they are effective at all. Bank regulation has so far been the dominant approach to tame risky banks. For example, in response to the financial crisis, the Basel III agreement of September 2010 tightened capital requirement rules to increase equity buffers and make the banking system more resilient to shocks. The same goal - discouraging low capitalization - may be achieved by designing the tax system such that it does not reward excessive debt financing. Keen (2011) provides a theoretical analysis of the interaction between regulation and taxation, building on a seminal study by Weitzman (1974). Whereas in theory, tax and regulation policies may be considered perfect substitutes, practical considerations suggest that both policy instruments should be used.

The efficiency of regulatory measures has been explored in a number of studies, especially in the context of risk taking (Admati et al. 2010; Hart and Zingales 2011). Several European countries followed suggestions by the IMF and implemented bank levies as a reaction to the financial crisis. Devereux et al. (2013) analyze the impact of these levies and find evidence that they indeed did cause an increase in capital stocks of banks. At the same time, however, such a levy could result in an increase of risk in a bank's assets and therefore undermine the benefit of additional capital (Devereux 2014). So far, only little is known how such policies affect the international allocation of financial sector FDI and particularly how sensitive MNCs' location decisions respond to tax vs. regulation policy.

This paper contributes to the literature on the determinants of financial sector FDI in a number of ways. First, using data on the universe of German outbound financial services FDI, we consider all new location choices of German MNCs over a time span of 13 years. Second, we analyze the effects of tax and regulation policy using new data on 83 potential host countries. Third, we provide estimates on own- and cross-elasticities to learn about how a change in tax 
and regulation policy of one country affects not only the probability that this country is chosen as a location but also how this affects the location probabilities of other countries.

Only very few papers have studied how taxes affect financial services FDI before. A recent contribution by Huizinga et al. (2014) finds that banking FDI is determined by host country taxes. Moreover, Claessens et al. (2001) find that low host country taxes are associated with additional banking FDI. Evidence on regulation policy and location choices of multinational banks is similarly scarce. While a number of papers examine how financial sector FDI is affected by regulation policy (e.g., Buch and Lipponer 2007; Tsai et al. 2011), none of these papers has analyzed how regulation policy affects the extensive margin of foreign activity in a discrete choice model.

Our analysis is based on financial services FDI data provided by Deutsche Bundesbank (the German central bank). This data allows us to identify new establishments of German multinationals all over the world during the period 2000-2012. In an average year during this period, about 250 new entities have been established by German MNCs in foreign countries. The most important host countries for financial services FDI are the US, where 760 new entities have been established over the whole time span considered, the UK, where we count 524 new establishments, and the Netherlands with 251 new establishments.

Our preferred specification - using a mixed logit estimation approach - implies a significant impact of tax and regulation variables on location probabilities. We find significant heterogeneity of tax responses. For example, if the tax is cut by 1 percent in Great Britain, the probability of attracting financial sector FDI increases by about 1.1 percent. In contrast, a 1 percent tax cut in Spain increases the location probability of Spain by only 0.3 percent. If regulation in Canada becomes more lenient as the country reduces capital requirements by 1 percent, the probability of attracting new financial sector entities from Germany is increased 
by almost 8 percent, ceteris paribus. Thus, while our results imply a lot of heterogeneity in terms of estimated elasticities, a general result is that tax and regulation policy can be used to attract financial sector FDI.

Our estimation approach also allows us to compute cross-elasticities that suggest interesting substitution patterns. For example, if Great Britain cuts its local tax rate by 1 percent, Great Britain will gain (see above) at the expense of other countries like China, whose location probability will be reduced by 0.107 percent. Such findings have policy implications, as uncoordinated policy action of one country imposes an externality on other countries. Hence, particularly regulation policy should be coordinated across countries.

The remainder of the paper is organized as follows. Section 2 briefly introduces a generic theoretical framework, which our empirical analysis is based on. In Section 3 we discuss the determinants of financial sector FDI. Section 4 explains the empirical approach and describes the data. Empirical results are presented in Section 5. Section 6 concludes.

\section{The Extensive Margin of Financial Sector FDI}

Our empirical analysis is based on a theoretical concept of comparison of expected profits across alternatives (countries). ${ }^{4}$ Let us denote profits of a multinational firm $b$ arising at a foreign financial services entity established in country $j$ as $\pi_{b j}^{*}$. The asterisk indicates that $\pi_{b j}$ is a latent variable, which is not observed by the researcher. The actual choice of firm $b$ - the location choice or extensive margin of foreign investment activity - is based on the maximum attainable profit when choosing one of $j=0,1,2, \ldots, J$ potential host countries:

$$
\pi_{b}=\operatorname{argmax}\left(\pi_{b 0}^{*}, \pi_{b 1}^{*}, \pi_{b 2}^{*}, \ldots, \pi_{b J}^{*}\right)
$$

\footnotetext{
${ }^{4}$ This has been introduced by McFadden (1974) who showed that an empirical discrete choice model - as the one we are using in this paper - can be obtained from a theoretical model of utility comparison.
} 
Below, we will define a binary choice indicator which takes on value one for the respective alternative chosen (where profits are highest), and zero for all the other alternatives not chosen. Thus, above equation suggests that all variables affecting $\pi_{b j}^{*}$ will determine in which country a firm $b$ is locating its foreign business. We may say that any generic variable $x_{j}$ that positively affects profits, $\frac{\partial \pi_{b j}^{*}}{\partial x_{j}}>0$, will make it more likely to increase the probability that $b$ chooses a particular location. The potential determinants $x_{j}$ affecting $\pi_{b j}^{*}$ will be discussed in the following sections.

\section{Determinants of Financial Sector FDI}

Previous literature on the determinants of financial sector FDI has mainly focused on foreign investments of multinational banks. One part of this literature has examined which banks become multinational and found that the size of a bank (Focarelli and Pozollo 2001; Clarke et al. 2003; Buch und Lipponer 2007; Temesvary 2014a), its balance sheet health (Popov and Udell 2012), and its productivity (Buch et al. 2014) are particularly important determinants. This paper is interested in how a financial services firm chooses a location for its foreign activity. The following sections will present an overview on the literature that identified a number of host-country characteristics that seem to be important determinants for location decisions of multinational banks. ${ }^{5}$

\subsection{Determinants of Financial Services FDI}

Many determinants of goods trade and FDI will be similarly important in context of financial services FDI. First, the distance between host country and home country of a firm is considered to be one major driver of economic integration. While in case of goods trade distance is associated with transportation costs, distance seems to be important for financial

\footnotetext{
${ }^{5}$ In these studies, the role of policy instruments like tax and regulation policies are often neglected, however.
} 
services as it affects the availability and quality of information. The specific business model of banks requires collecting and processing information on customers to provide financial services on competitive terms (Rajan 1992; Petersen and Rajan 2002). Thus, a lower distance between the home country and the host country of an investment should be favorable since this reduces information asymmetries between headquarters or parents and foreign entities (Berger et al. 2004; Liberti and Mian 2009). Several studies found empirical evidence for distance as an important determinant of investment locations (Focarelli and Pozzolo 2005; Buch and Lipponer 2007; Claessens and van Horen 2014). As more and more companies started to export to foreign markets and became multinational firms, financial services across borders became more important as well. Several studies demonstrate that foreign activities of banks and bilateral trade volumes between countries are positively correlated (Brealey and Kaplanis 1996; Yamori 1998; Buch 2000; Berger et al. 2004; Focarelli and Pozzolo 2001, 2005). Other determinants of foreign banking relate to cultural characteristics such as common language, which should facilitate the successful market entry in a host country. Evidence suggests that cultural variables are important determinants of international banking (Buch 2003; Focarelli and Pozzolo 2005). Moreover, a wide range of host-country characteristics that affect the profitability of foreign entities should have an impact on the location choice of financial services firms. For example, previous studies show that market size and GDP per capita are associated with additional bank FDI (Yamori 1998; Buch 2000; Claessens et al. 2001; Cerruti et al. 2007). Focarelli and Pozzolo (2001; 2005) identify expected economic growth in the host country and local bank inefficiencies as additional determinants of location choices.

Finally, very recent literature focuses on the effects of the financial crisis on banking sector FDI. Several studies find a decline in foreign activities associated with the financial crisis (Cetorelli and Goldberg 2009, 2011; Temesvary 2014a, 2014b). Buch et al. (2014) provide 
evidence that the changing market conditions triggered by the financial crisis led banks to reduce their international assets. In addition, they identify policy interventions and banks' increasing sensitivity towards financial frictions as main drivers behind this reduction.

\subsection{Bank Regulation}

One argument often used in policy debate is that deregulation policy has been responsible for the rampant expansion of banking across the world (Buch 2003). ${ }^{6}$ In line with this view, regulatory requirements are expected to increase market entry costs and deter foreign activity (Lehner 2009; Tsai et al. 2011). In a similar way, if regulators impose high capital (equity) requirements and liquidity rules, this should unambiguously increase a bank's cost of capital and therefore have a negative effect on foreign activity. On the other hand, enhanced transparency through tight government regulation and supervision might reduce aforementioned information asymmetries and could even facilitate foreign activity. Buch (2003) argues that the effect of regulatory requirements might also differ across countries, and finds a limiting effect of tighter regulation on foreign activity, on average.

Buch and Lipponer (2007) confirm a negative relationship between bank FDI and higher capital controls. However, a tight regulatory supervisory system in the host country does not necessarily limit foreign FDI. Buch and DeLong (2004) argue that the effect of information costs on banks' cross-border mergers is far more pronounced than the effect of regulation costs. Temesvary $(2014 a ; 2014 b)$ examines a sample of US banks and the effects of hostcountry characteristics on foreign banking activities. Her results indicate that market entry costs, which in her sample are associated with regulatory constraints, have a negative impact on banks' foreign activities. In contrast, Bertus et al. (2008) find no connection between foreign bank ownership and the regulatory framework in a particular country.

\footnotetext{
${ }^{6}$ Moreover, research has been concerned in the relationship between deregulation and excessive risk taking (Keeley 1990; Hovakimian and Kane 2000; Admati et al. 2010; Hart and Zingales 2011).
} 


\subsection{Taxation}

Corporate income taxes reduce the return on investment available for the shareholder. In an international context, a foreign affiliate of a multinational firm is subject to tax in its host country. Therefore, a low tax at the host location is associated with higher residual income that can be distributed to the parent firm. The repatriation of income is then usually exempt from home country taxation. ${ }^{7}$ A number of studies have analyzed the influence of taxes on FDI (for reviews cf. De Mooij and Ederveen 2003, 2005; Feld and Heckemeyer 2011). Only relatively few papers analyzed how taxes affect the extensive margin of foreign activity by focusing on location decisions of multinational firms. These studies provide evidence that host country taxes exert a negative effect on location probabilities (Devereux and Griffith 1998; Grubert and Mutti 2004; Buettner and Ruf 2007; Buettner and Wamser 2009; Barrios et al. 2012).

While none of the studies mentioned above considers financial sector FDI, the findings in Overesch and Wamser (2009) suggest that financial sector FDI is particularly responsive to taxes. The study distinguishes between FDI from different industries among them financial services. The results show that the responses to host country taxes differ significantly across different business activities. Although their data does not include multinational banks, their estimates suggest a particularly strong effect of corporate taxes on location choices of subsidiaries that provide financial services within multinational firms. To the best of our knowledge, only two more studies have analyzed the impact of taxes on FDI of multinational banks. Claessens et al. (2001) find a negative relationship between host country tax rate and banking FDI. Huizinga et al. (2014) find that international double taxation of dividends reduces banking FDI. However, these studies use information about bank assets, while our

\footnotetext{
${ }^{7}$ Only the US and a small number of other countries consider all types of foreign income as part of taxable profits of the parent corporation. At the same time, these countries usually provide tax credits on taxes paid abroad. This system is, however, not relevant for our paper, as Germany exempts all foreign income from taxation in the home country.
} 
paper focusses on the question of how taxes affect the choice among alternative locations when setting up a new foreign financial services entity.

\section{Empirical Approach and Data}

\subsection{Mixed Logit}

We are interested in the determinants of location choices of multinational banks and particularly how taxes and regulation affect these choices. We base our empirical analysis on a mixed logit model, which is associated with a number of favorable features that are important with respect to the specific research goals we have in this paper. In particular, the two main advantages are (i) that the mixed logit allows us to learn about (realistic) substitution patterns across alternatives and (ii) that it allows for correlation in unobserved factors across alternatives (countries).

A very intuitive interpretation of the mixed logit model is one of error components creating correlations among the profits for different alternatives (see Train 2009). As outlined in Section 2, the underlying model we have in mind when multinational firm $b$ chooses a foreign location is one where the firm maximizes profits $\pi_{b j}^{*}$.

Let us neglect the asterisk we used to denote latent variables and specify profits of multinational bank $b$ obtained from alternative (country) $j$ as

$$
\pi_{b j t}=\alpha^{\prime} x_{b j t}+\mu_{b}^{\prime} z_{b j t}+\varepsilon_{b j t}
$$

The vectors $x_{b j t}$ and $z_{b j t}$ denote observed country-j-specific characteristics. While $\alpha$ is a vector of fixed coefficients to be estimated, $\mu_{b}$ is a vector of random terms with zero mean, and $\varepsilon_{b j t}$ is assumed to be independently, identically distributed extreme value. To the extent that $x_{b j t}$ and $z_{b j t}$ are indexed by $t$, we allow each of these variables to depend on the 
respective observables in a given year $t$. We will also consider that one firm may face different choice situations over time, but then treat coefficients $\mu_{b}$ that enter utility as constant for each $b$. Note that we want to specifically model a choice as one where $b$ chooses from alternatives, so that the focus is on cross-sectional variation in determinants. Of course, since $\mu_{b}$ is indexed by multinational $b$, coefficients vary across firms. One of the key issues in specifying this model is the choice of $z_{b j t}$. Together with $\varepsilon_{b j t}, z_{b j t}$ defines the stochastic portion of profits as $\theta_{b j t}=\mu_{b}^{\prime} z_{b j t}+\varepsilon_{b j t}$ (Train 2009). By specifying $z_{b j t}$, we allow for correlation across alternatives (countries) $i$ and $j,{ }^{8}$ so that $\operatorname{Cov}\left(\theta_{b i t}, \theta_{b j t}\right)=E\left(\mu_{b}^{\prime} z_{b i t}+\right.$ $\left.\varepsilon_{b i t}\right)\left(\mu_{b}^{\prime} z_{b j t}+\varepsilon_{b j t}\right)=z_{b i t}^{\prime} W z_{b j t}$, with $W$ being the covariance of $\mu_{b}$.

The specific variables included in $x_{b j t}$ and $z_{b j t}$ are discussed in more detail below. While $x_{b j t}$ will capture country characteristics such as the log of a country's GDP or the geographical distance to Germany, the specification of $z_{b j t}$ is important as these variables induce correlation over alternatives. Since we are interested in cross-country elasticities related to tax and bank regulation policy, $z_{b j t}$ includes country $j$ 's tax rate and different measures for regulation. In the presence of profit shifting, if MNCs operate internal capital markets or if other intra-firm relations are important, it is highly likely that these variables induce correlation across alternatives' unobserved parts. ${ }^{9}$

\footnotetext{
${ }^{8}$ The conditional logit does not allow for correlation in the unobserved parts of $\pi_{b j}^{*}$, which gives rise to the socalled IIA (independence from irrelevant alternatives) assumption. Besides providing consistent estimates on tax and regulation variables, we are particularly interested in substitution patterns across countries. Hence, we need to relax this assumption as it would imply a proportional shifting pattern across alternatives.

${ }^{9}$ Another interpretation of the mixed logit model is one of a random coefficient model. It seems highly likely that firms respond very heterogeneously to taxes, depending on the extent to which firms can avoid taxes, for example.
} 


\subsection{Financial Services FDI Data}

Our empirical analysis is based on the micro-level dataset MiDi (Micro Database $\underline{\text { Direct }}$ Investment) provided by Deutsche Bundesbank (the German central bank). MiDi is a panel dataset on foreign direct investment positions of German investors. It basically records information about the investment object's balance sheet, some information on the type of investment (e.g., industry), and limited information on the investor. Particularly noteworthy is that German law enforces data collection of foreign activity of German investors, ${ }^{10}$ which enables us to observe virtually all German outbound activity.

While MiDi reports foreign investments across all different industries, we will focus on a subsample of financial services entities of German multinationals. To be included in our dataset, the latter are required to have a direct participating interest in the foreign entity of more than $50 \%$ (majority owners). However, the German headquarters do not necessarily have to operate in the financial sector. These restrictions leave us with 839 MNCs that establish 3,790 new financial sector entities (between 2000 and 2012) in 83 host countries. ${ }^{11}$ The vast majority of foreign entities are legally independent subsidiaries (3,546 ones) only few are set up as branches.

For each of the 3,790 newly established subsidiaries, we consider which location is effectively chosen among the 83 potential host countries. As our dependent variable we compute an indicator variable $L O C D E C_{b j t}$ that equals 1 for the location effectively chosen and zero for the $J-1$ (82) alternative host countries not chosen. Considering the information of all location

\footnotetext{
${ }^{10}$ Section 26 of the Foreign Trade and Payments Act (Aussenwirtschaftsgesetz) in connection with the Foreign Trade and Payment Regulations (Aussenwirtschaftsverordnung).

${ }^{11}$ An overview is given in Table 8, see the Appendix.
} 
choices in the financial sector between 2000 and 2012, our sample includes 309,912 observations. $^{12}$

\subsection{Tax and Regulation Data}

Regarding tax incentives we consider the statutory corporate tax rate, $S T R_{j t}$, to capture expected tax payments in a host country of foreign entities. ${ }^{13}$ This variable is collected by the authors from different sources (International Bureau of Fiscal Documentation, IBFD; tax surveys provided by Ernst\&Young, PwC, and KPMG). Another tax variable is $D T T_{j t}$ which measures the total number of double taxation treaties concluded by a host country $j$. This variable is available from the United Nations Conference on Trade and Development (UNCTAD) and is included as a tightly-knit network of DTTs may facilitate cross-border capital flows of dividends, interest, and royalties, which might be important for the multinational bank.

To account for host countries' regulatory framework we rely on three different variables. First, $R A T I O_{j t}$ measures the equity ratio required in the respective host country. This variable was taken from several waves of a survey conducted by Barth et al. (2001). ${ }^{14}$ Since increased equity requirements are usually assumed to impose a cost on firms, we expect a negative effect on foreign activities. In our data, $R A T I O_{j t}$ varies between 0.05 and 0.19 . Many countries impose minimum equity ratios as suggested by Basel II regulation (0.08), some countries like Nigeria or the United Arab Emirates require significantly higher equity ratios (0.19 and 0.12).

\footnotetext{
12 The total number of observations is not $314,570(=3,790 \cdot 83)$ due to missing control variables for some country-year pairs.

${ }^{13}$ Concerning Luxemburg, we assume a statutory tax rate of zero due to Luxembourg's known holding regimes and ruling system. However, alternative regressions in which we excluded Luxemburg confirm our results.

${ }^{14}$ The survey was repeated with the current 4th round being published in 2012.
} 
The second measure we use to capture the regulatory environment is called $R E G_{j t}{ }^{15}$ This variable is also based on an index developed by Barth et al.'s (2001) survey published by the World Bank. ${ }^{16}$ It consists of four components indicating the strictness of jurisdictions when banks engage in financial activities. To be specific, $R E G_{j t}$ is defined as the sum over the four variables $R S E C_{j t}, R I N S_{j t}, R R E A L_{j t}$, and $R N O N F I N_{j t}$. Each of these variables is increasing in the strictness of how a country $j$ is regulating banks' activities in securities $\left(R S E C_{j t}\right)$, insurance $\left(R I N S_{j t}\right)$, real estate $\left(R R E A L_{j t}\right)$, or non-financial activities $\left(R N O N F I N_{j t}\right)$. Strictness is measured by scores ranging from 1 to $4 .{ }^{17}$ Our variable $R E G_{j t}$ combines all four categories into one measure. Higher values in $R E G_{j t}$ are associated with a less attractive location for banks. In our data, Indonesia exhibits the highest value (16) of $R E G_{j t}$.

Banks are not only incentivized by their own tax planning opportunities, they may also have good reason to establish branches and subsidiaries in locations favored by their clients. Therefore, in additional specifications, we add $B A N K S E C_{j}$ to account for the level of secrecy of the respective location when it comes to tax issues. ${ }^{18}$

It may be interesting to see how regulation policy relates to tax policy. To do this, we have produced Figures 1 and 2. In both figures, $S T R_{j}$ (averaged over all years in our sample) is displayed on the horizontal axis, while the measures for regulation are displayed on the vertical axes $\left(R A T I O_{j}\right.$ in Figure $1 ; R E G_{j}$ in Figure 2). Very surprisingly, it seems that regulation policy is only weakly (negatively) related to tax policy in case of $R A T I O_{j}$ : higher taxes may allow for laxer regulation. Both figures illustrate that there is a lot of variation across countries in the main variables of interest for this study.

\footnotetext{
${ }^{15}$ Cerruti et al. (2007) and Tsai et al. (2011) use the index in a similar context.

${ }^{16}$ An overview on the data and survey updates can be found at http://go.worldbank.org/SNUSW978P0.

${ }^{17}$ A value of 1 for $R S E C_{j t}$, as an example, indicates that a full range of securities activities can be conducted directly by banks. The strictest value which equals 4 indicates that none of these activities can be done in either banks or their subsidiaries in the respective country.

${ }^{18}$ We use this variable only in robustness tests. The reason is that due to a poor coverage across countries, we lose about half of the observations compared to our basic specification.
} 
FIGURE 1: TAX vs. regulation policy (RATIO)

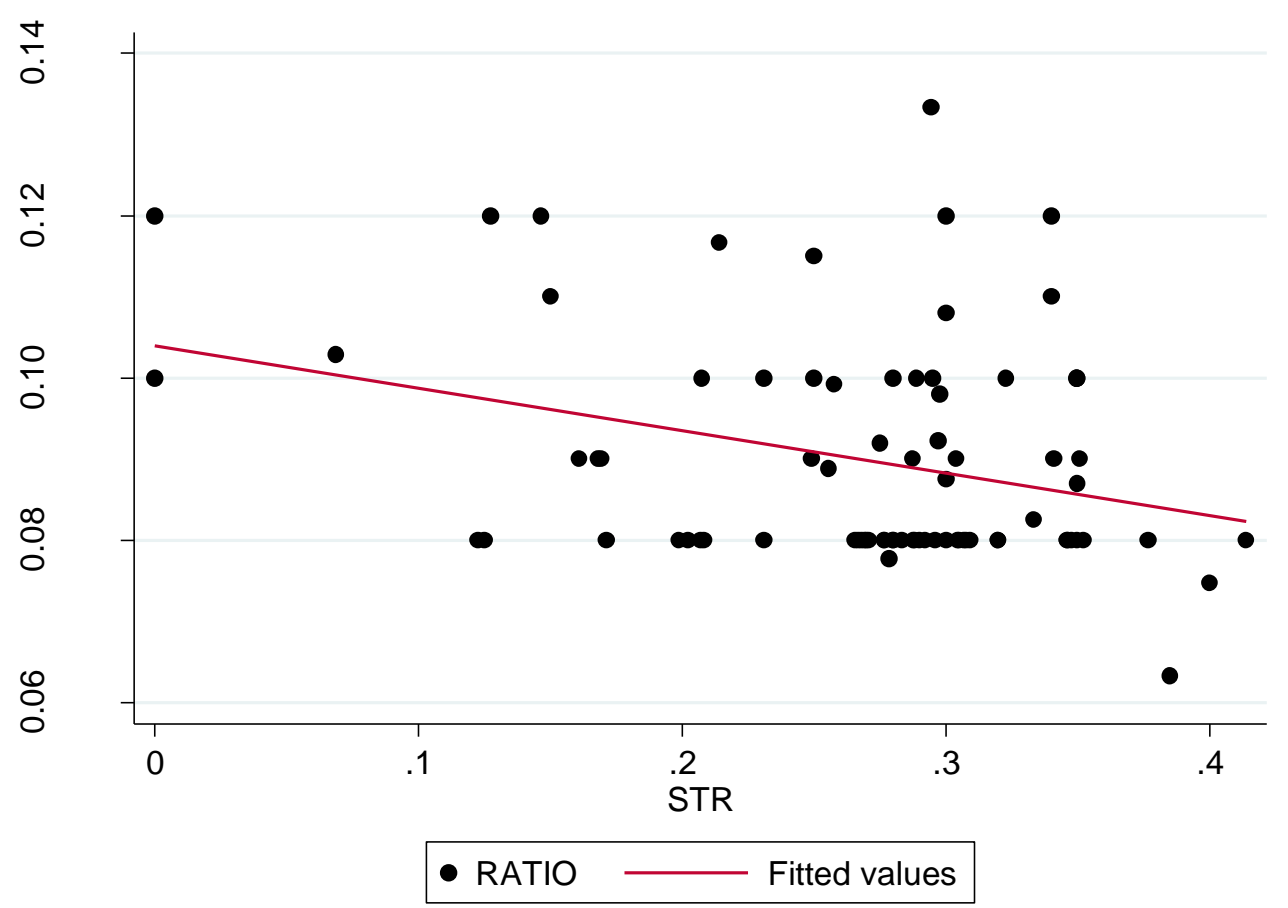

FIGURE 2: TAX vs. regulation policy (REG)

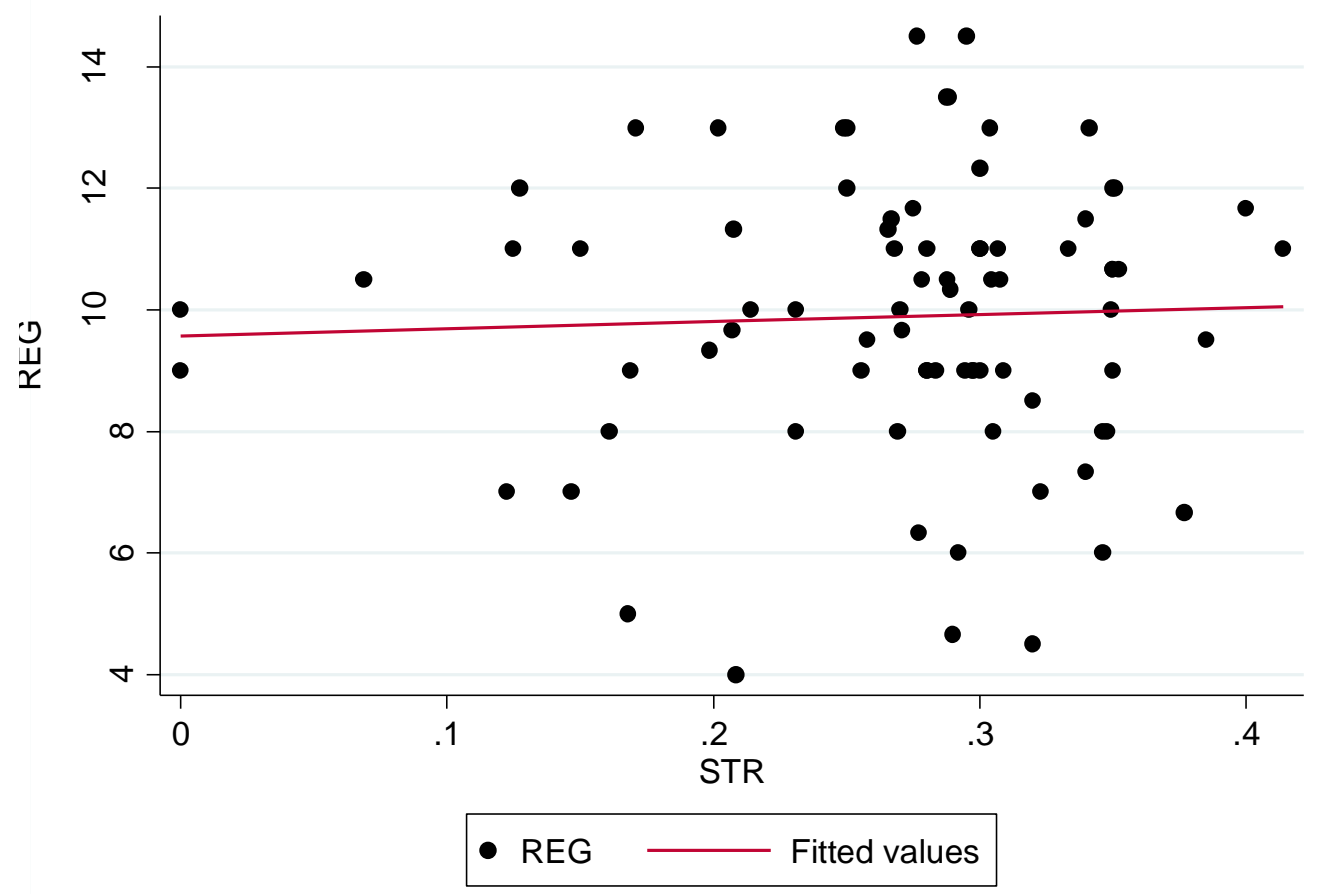




\subsection{Non-Tax and Non-Regulation Determinants}

In line with existing work on the determinants of FDI, we consider the following non-tax and non-regulation variables. First, to capture the size of the local market, we use $(\log ) G D P_{j t}$. Second, the growth of GDP in country $j, G D$ Prowth $_{j t}$, is included to capture growth possibilities. Both variables are taken from the World Bank's World Development Indicators. In addition, we use variables to control for cultural and geographical distance between Germany (the country of the investors) and host countries $j$. The geographical distance is denoted by $(\log ) D I S T_{j}, C O N T_{j}$ and $C O M L A N G_{j}$ are dummy variables indicating whether host country $j$ shares a common border with Germany $\left(C O N T_{j}\right)$ and whether German is an official language in the host country $\left(C O M L A N G_{j}\right)$. More distant countries (in geographical distance and cultural distance) are expected to attract less FDI. In particular, as communication and information exchange is important in context of financial services FDI, we expect these variables to be important determinants with a negative expected sign for $(\log ) D I S T_{j}$; variables $C O N T_{j}$ and $C O M L A N G_{j}$ should positively relate to the probability that country $j$ is chosen. All latter three variables are taken from the Centre d'Études prospectives et d'Informations Internatinales (CEPII).

Similar to the DTT variable as introduced above, we use the number of bilateral investment treaties concluded by country $j, B I T_{j t}$. Bilateral investment treaties have been shown to be an effective policy instrument to attract FDI as they reduce foreign market entry cost (Egger and Merlo 2012). BITs may be less relevant, however, in the context of financial sector FDI. The information on BITs is taken from UNCTAD. 


\section{Results}

Table 1 presents basic results from mixed logit estimations. As argued above, we specify tax and regulation variables as random $\left(S T R_{j t}, R A T I O_{j t}, R E G_{j t}\right)$, while all other control variables are defined as fixed. The results show that tax and regulation responses are heterogeneous across firms (see also the highly significant estimates for the standard deviations), but the mean coefficients are estimated with the expected signs: A higher tax at location $j$ leads to less financial sector FDI, stricter regulation in form of stricter capital requirements, as well as higher values of the regulation index are associated with less financial sector FDI. The estimated coefficients for the variables entering as fixed are in line with theoretical expectations. Only the negative estimate for GDPgrowth $h_{j t}$ may seem unusual. One explanation for this is that more growth allows local and multinational firms to finance locally through their own earnings. Another explanation may be that financial sector FDI often goes to already developed countries which exhibit usually rather low or modest GDP growth rates. Less distant countries in terms of cultural distance $\left(C O M L A N G_{j}\right)$ between Germany and host country $j$ as well as geographical distance $\left(D I S T_{j}\right)$ increase the probability to be chosen as host country, as expected.

Before providing some quantitative interpretations of these results, we may look at predicted base probabilities for a country to be chosen as a host location. Table 2 shows that the base probability is predicted to be relatively low (below 1 percent) for countries like Australia $(\mathrm{AUS}=0.0061)$, Hong Kong $(\mathrm{HKG}=0.0070)$ or Singapore $(\mathrm{SGP}=0.0046)$, and relatively high for countries like the United States (USA $=0.0955)$, Austria $($ AUT $=0.0368)$ or Belgium $(\mathrm{BEL}=0.0483)$. However, the country for which we predict the highest base probability is Great Britain, for which we estimate a base probability that exceeds 10 percent. 
TABLE 1: Basic Results

\begin{tabular}{|c|c|c|c|c|}
\hline \multirow[b]{2}{*}{ Coefficients } & \multicolumn{2}{|c|}{ (1) } & \multicolumn{2}{|c|}{ (2) } \\
\hline & $\underline{\text { Mean }}$ & $\underline{S D}$ & $\underline{\text { Mean }}$ & $\underline{S D}$ \\
\hline $\begin{array}{l}\text { STR }_{\text {jt }} \\
\text { RATIO }_{\mathbf{j t}} \\
\text { REG }_{\mathbf{j t}}\end{array}$ & $\begin{array}{l}-5.364 * * \\
(0.461) \\
-55.27 * * \\
(5.90)\end{array}$ & $\begin{array}{l}7.642 * * \\
(0.482) \\
42.58 * * \\
(4.08)\end{array}$ & $\begin{array}{l}-5.081 * * \\
(0.470) \\
-58.07 * * \\
(5.72) \\
-0.107 * * \\
(0.015)\end{array}$ & $\begin{array}{c}8.149 * * \\
(0.804) \\
45.50 * * \\
(4.24) \\
0.165 * * \\
(0.016)\end{array}$ \\
\hline $\begin{array}{l}\text { Coefficients } \\
\text { specified as } \\
\text { fixed: }\end{array}$ & & & & \\
\hline $\operatorname{lnGDP}_{\mathrm{jt}}$ & $\begin{array}{l}0.779 * * \\
(0.028)\end{array}$ & & $\begin{array}{l}0.784^{* *} \\
(0.028)\end{array}$ & \\
\hline GDP growth $_{\mathrm{jt}}$ & $\begin{array}{l}-0.050 * * \\
(0.009)\end{array}$ & & $\begin{array}{l}-0.052 * * \\
(0.009)\end{array}$ & \\
\hline $\operatorname{lnDIST}_{\mathbf{j t}}$ & $\begin{array}{l}-0.529 * * \\
(0.032)\end{array}$ & & $\begin{array}{l}-0.376^{* *} \\
(0.037)\end{array}$ & \\
\hline COMLANG $_{\mathrm{jt}}$ & $\begin{array}{l}0.833 * * \\
(0.074)\end{array}$ & & $\begin{array}{l}0.821 * * \\
(0.074)\end{array}$ & \\
\hline CONTIG $_{\text {it }}$ & $\begin{array}{l}-0.298 * * \\
(0.066)\end{array}$ & & $\begin{array}{l}-0.018 \\
(0.070)\end{array}$ & \\
\hline $\mathbf{D T T}_{\mathbf{j t}}$ & $\begin{array}{l}0.013 * * \\
(0.001)\end{array}$ & & $\begin{array}{l}0.013 * * \\
(0.002)\end{array}$ & \\
\hline $\mathbf{B I T}_{\mathrm{jt}}$ & $\begin{array}{l}-0.009 * * \\
(0.001)\end{array}$ & & $\begin{array}{l}-0.009 * * \\
(0.001)\end{array}$ & \\
\hline$N$ & 309,912 & & 309,912 & \\
\hline
\end{tabular}

Notes: Mixed logit estimates; 3,790 positive location choices. Random variables: STR is the statutory corporate tax rate of the subsidiary's host country. RATIO equals the minimum equity ratio required in the host country. REG is an indicator for restrictions in different activities. Fixed variables: lnGDP is host country GDP in logs, GDP growth indicates yearly growth in host country GDP. InDIST is the distance between home country and host country in logs. COMLANG is a dummy variable indicating a common official language. CONTIG is a dummy variable for a common boarder. DTT and BIT equal the number of double tax treaties and bilateral investment treaties of the host country respectively. $*$ and ** indicate significance at the 5\% and $1 \%$ level. More information concerning control variables is provided in Table 6 in the Appendix. 
TABLE 2: Estimated Base Probabilities for 12 Selected Countries

\begin{tabular}{c|c|c|c|c|c}
\hline Country & Base Prob. & Country & Base Prob. & Country & Base Prob. \\
\hline AUS & 0.0061 & CHN & 0.0216 & IRL & 0.0357 \\
AUT & 0.0368 & ESP & 0.0231 & RUS & 0.0232 \\
BEL & 0.0483 & GBR & 0.1241 & SGP & 0.0046 \\
CAN & 0.0231 & HKG & 0.0070 & USA & 0.0955 \\
\hline
\end{tabular}

\subsection{Own- and Cross-Elasticities for Changes in Tax and Regulation Variables}

Our estimation approach not only allows us to find out about how a change in a policy variable of country $j$ affects the probability to locate in country $j$, it also allows us to find out about substitution elasticities across alternatives (countries). For example, we may answer questions of the following type: How does a 1 percent change in taxes in the US affect the probability to locate in the US, in Canada, or in the UK. We present estimates on own- and cross elasticities for a number of countries in Tables 3 and 4. Before discussing the results, let us look at the formal representation of how a change in the $m$ th element of the vector of explanatory variables (e.g. RATIO) of one country, say $j$, affects the location probability of country $i$ (see Train 2009). Expressed as an elasticity, the percentage change in the probability is given by

$$
E_{b i z_{b j}^{m}}=-\frac{z_{b j}^{m}}{P_{b i}} \int \mu^{m} L_{b i}(\mu) L_{b j} f(\mu) d \mu=-z_{b j}^{m} \int \mu^{m} L_{b j}(\mu)\left[\frac{L_{b i}(\mu)}{P_{n i}}\right] f(\mu) d \mu .
$$

This representation of the change in location probability highlights that changes in probabilities depend on the correlation between $L_{b i}(\mu)$ and $L_{b j}(\mu)$, which denote the choice probabilities over different values of $\mu$. This implies that substitution patterns crucially depend on the specification of explanatory variables and the assumption on the mixing distribution. Tables 3 and 4 present own- and cross-elasticities for STR and RATIO and the same selection of countries as in Table 2. The tables are organized such that each cell 
provides the tax or regulation effect on a country in a row with respect to a 1 percent increase of $S T R(R A T I O)$ of the country in a column. For example, if Singapore reduces its tax rate by 1 percent, all other countries lose in terms of lower location probabilities. However, our estimation approach allows that the reduction in probability mass is heterogeneously distributed across countries, i.e. some countries lose more (e.g., Hong Kong) than others (e.g., Belgium). The bold diagonal elements in the respective table denote own-elasticities. For example, if the tax is cut by 1 percent in Great Britain (GRB), the probability of attracting financial sector FDI increases by about 1.01 percent. Although a tax of a given country usually comes at the cost of other countries (one country attracts FDI at the expense of others), our results suggest interesting complementarities for some country-relations. For example, while we expect a US-tax-cut-policy to attract new financial services entities, there seem to be positive spillovers to other countries. In particular, countries that are associated with a high cultural or geographical proximity to the US (as Australia or Canada) benefit from lower taxes there. Such complementarities are in line with learning arguments that arise within multinational firm networks (Egger et al. 2014a).

Table 4 further suggests that the responsiveness of German financial services FDI to regulation at the extensive margin is highly sensitive, expressed in form of elasticities. The estimated own-elasticities range from about 4 (RUS) to 9.2 (SGP). For example, a 1 percent lower capital ratio (a 1 percent lower equity requirement) imposed by Great Britain is estimated to increase the probability to locate there by about 5.3 percent. The estimates confirm that RATIO is an extremely important determinant of location choice and that locations with lax capital requirements are particularly attractive for German MNCs. Other than in case of $S T R$, the estimated cross-elasticities are negative, irrespective of the country combination. Given the way how we have specified the vector of random variables, and given significant differences in countries' tax incentives, the finding of (some) positive tax-cross- 
elasticities (and throughout negative regulation-cross-elasticities at the same time) is fully consistent with profit-shifting considerations. In fact, the latter explains why tax responses differ in the first place (Egger et al. 2014b).

TABLE 3: Own- and Cross-Elasticities of a One-Percent Tax Cut for a Selection of Countries

\begin{tabular}{|c|c|c|c|c|c|c|c|c|c|c|c|c|}
\hline & AUS & AUT & BEL & CAN & CHN & ESP & GBR & HKG & IRL & RUS & SGP & USA \\
\hline AUS & $\mathbf{1 , 1 4 8}$ & $-0,463$ & $-0,024$ & $-0,117$ & $-0,318$ & $-0,006$ & $-0,120$ & $-0,081$ & $-0,030$ & $-0,025$ & $-0,007$ & 0,003 \\
\hline AUT & $-0,009$ & $\mathbf{1 , 4 1 8}$ & $-0,048$ & $-0,021$ & $-0,028$ & $-0,018$ & $-0,206$ & $-0,015$ & $-0,045$ & $-0,042$ & $-0,010$ & $-0,027$ \\
\hline BEL & $-0,003$ & $-0,029$ & $\mathbf{0 , 5 7 5}$ & 0,006 & $-0,013$ & 0,015 & $-0,068$ & $-0,006$ & $-0,021$ & $-0,019$ & $-0,004$ & 0,091 \\
\hline CAN & $-0,003$ & $-0,025$ & 0,013 & $\mathbf{0 , 5 0 9}$ & $-0,015$ & 0,018 & $-0,061$ & $-0,006$ & $-0,020$ & $-0,016$ & $-0,005$ & 0,111 \\
\hline CHN & $-0,009$ & $-0,044$ & $-0,036$ & $-0,020$ & $\mathbf{1 , 3 5 7}$ & $-0,014$ & $-0,107$ & $-0,007$ & $-0,031$ & $-0,021$ & $-0,012$ & $-0,056$ \\
\hline ESP & $-0,013$ & $-0,022$ & 0,029 & 0,017 & $-0,010$ & $\mathbf{0 , 2 8 7}$ & $-0,039$ & $-0,006$ & $-0,018$ & $-0,014$ & $-0,005$ & 0,145 \\
\hline GBR & $-0,006$ & $-0,060$ & $-0,033$ & $-0,014$ & $-0,019$ & $-0,010$ & $\mathbf{1 , 0 7 8}$ & $-0,012$ & $-0,036$ & $-0,037$ & $-0,007$ & $-0,006$ \\
\hline HKG & $-0,013$ & $-0,132$ & $-0,093$ & $-0,040$ & $-0,037$ & $-0,042$ & $-0,357$ & $\mathbf{1 , 6 2 6}$ & $-0,091$ & $-0,082$ & $-0,019$ & $-0,081$ \\
\hline IRL & $-0,015$ & $-0,122$ & $-0,093$ & $-0,044$ & $-0,052$ & $-0,040$ & $-0,336$ & $-0,028$ & $\mathbf{1 , 3 2 0}$ & $-0,075$ & $-0,019$ & $-0,109$ \\
\hline RUS & $-0,008$ & $-0,078$ & $-0,057$ & $-0,024$ & $-0,024$ & $-0,021$ & $-2,360$ & $-0,017$ & $-0,051$ & $\mathbf{1 , 5 2 3}$ & $-0,009$ & $-0,043$ \\
\hline SGP & $-0,014$ & $-0,109$ & $-0,076$ & $-0,042$ & $-0,079$ & $-0,046$ & $-0,251$ & $-0,023$ & $-0,076$ & $-0,052$ & $\mathbf{1 , 8 2 6}$ & $-0,109$ \\
\hline USA & 0,000 & $-0,008$ & 0,040 & 0,023 & $-0,010$ & 0,032 & $-0,005$ & $-0,002$ & 0,011 & $-0,006$ & $-0,003$ & $\mathbf{0 , 0 8 5}$ \\
\hline
\end{tabular}

TABLE 4: Own- and Cross-Elasticities of a One-Percent Lower Capital Requirement for a Selection of Countries

\begin{tabular}{|c|c|c|c|c|c|c|c|c|c|c|c|c|}
\hline & AUS & AUT & BEL & CAN & CHN & ESP & GBR & HKG & IRL & RUS & SGP & USA \\
\hline AUS & $\mathbf{8 , 2 1 8}$ & $-0,318$ & $-0,430$ & $-0,211$ & $-0,207$ & $-0,209$ & $-0,846$ & $-0,058$ & $-0,216$ & $-0,091$ & $-0,050$ & $-0,749$ \\
\hline AUT & $-0,056$ & $\mathbf{7 , 3 5 2}$ & $-0,428$ & $-0,198$ & $-0,143$ & $-0,209$ & $-1,015$ & $-0,091$ & $-0,283$ & $-0,128$ & $-0,060$ & $-0,548$ \\
\hline BEL & $-0,060$ & $-0,336$ & $\mathbf{6 , 9 9 5}$ & $-0,236$ & $-0,154$ & $-0,250$ & $-0,974$ & $-0,058$ & $-0,180$ & $-0,100$ & $-0,038$ & $-0,760$ \\
\hline CAN & $-0,058$ & $-0,306$ & $-0,463$ & $\mathbf{7 , 7 1 6}$ & $-0,171$ & $-0,249$ & $-0,901$ & $-0,048$ & $-0,173$ & $-0,092$ & $-0,039$ & $-0,819$ \\
\hline CHN & $-0,063$ & $-0,244$ & $-0,335$ & $-0,187$ & $\mathbf{7 , 2 4 6}$ & $-0,162$ & $-0,589$ & $-0,042$ & $-0,207$ & $-0,064$ & $-0,070$ & $-0,880$ \\
\hline ESP & $-0,058$ & $-0,325$ & $-0,492$ & $-0,251$ & $-0,150$ & $\mathbf{7 , 6 3 4}$ & $-0,969$ & $-0,052$ & $-0,160$ & $-0,095$ & $-0,043$ & $-0,797$ \\
\hline GBR & $-0,052$ & $-0,363$ & $-0,444$ & $-0,206$ & $-0,117$ & $-0,223$ & $\mathbf{5 , 3 9 6}$ & $-0,079$ & $-0,249$ & $-0,130$ & $-0,043$ & $-0,546$ \\
\hline HKG & $-0,045$ & $-0,392$ & $-0,326$ & $-1,378$ & $-0,111$ & $-0,148$ & $-0,957$ & $\mathbf{8 , 3 3 7}$ & $-0,416$ & $-0,152$ & $-0,082$ & $-0,301$ \\
\hline IRL & $-0,045$ & $-0,335$ & $-0,276$ & $-0,133$ & $-0,144$ & $-0,122$ & $-0,846$ & $-0,115$ & $\mathbf{7 , 1 3 6}$ & $-0,140$ & $-0,076$ & $-0,326$ \\
\hline RUS & $-0,019$ & $-0,155$ & $-0,157$ & $-0,072$ & $-0,047$ & $-0,074$ & $-0,454$ & $-0,042$ & $-0,144$ & $\mathbf{3 , 8 7 5}$ & $-0,017$ & $-0,178$ \\
\hline SGP & $-0,062$ & $-0,405$ & $-0,338$ & $-0,175$ & $-0,286$ & $-0,194$ & $-0,846$ & $-0,129$ & $-0,434$ & $-0,097$ & $\mathbf{9 , 2 0 5}$ & $-0,492$ \\
\hline USA & $-0,061$ & $-0,246$ & $-0,447$ & $-0,248$ & $-0,242$ & $-0,240$ & $-0,707$ & $-0,028$ & $-0,117$ & $-0,061$ & $-0,032$ & $\mathbf{5 , 3 5 2}$ \\
\hline
\end{tabular}




\subsection{Robustness}

Table 5 includes 2 additional robustness specifications. In column (1) we add an indicator variable for a high level of bank secrecy taken from the OECD (2006). Since information about bank secrecy is not available for all countries, we can only consider a slightly smaller set of locations as in Table 1. However, almost all important host countries with a significant number of new financial service entities are included. We find a positive effect of bank secrecy on financial sector location decisions.

The second important finding is that the results for the tax rate and bank regulation variables are hardly affected: Table 5 still suggests a significant negative effect of a higher tax rate and higher capital requirement on the probability to set up a new entity in a certain country. Moreover, a high score for the overall level of bank regulation, indicating strict limitations, is again associated with a smaller probability to choose a host country.

In specification (2) of Table 5 we analyze if all regulation components affect location choices. Our results suggest that location choices are particularly responsive to restrictions of securities transactions but also to limitations of activities outside the financial sector, while restrictions of insurance activities and real estate transactions do not matter. Once again, our findings concerning taxes and capital requirements remain quite robust. 
TABLE 5: Robustness Checks

\begin{tabular}{|c|c|c|c|c|}
\hline & & & & \\
\hline Coefficients sp & & & & \\
\hline as random: & $\underline{\text { Mean }}$ & $\underline{S D}$ & $\underline{\text { Mean }}$ & $\underline{S D}$ \\
\hline$S T R_{j t}$ & $-3.34 * *$ & $7.35 * *$ & $-2.182 * *$ & $5.983 * *$ \\
\hline & $(0.47)$ & $(0.48)$ & $(0.504)$ & $(0.391)$ \\
\hline$R A T I O_{j t}$ & $-42.48 * *$ & $29.17 * *$ & $-26.08 * *$ & $22.93 * *$ \\
\hline & (6.06) & $(4.09)$ & $(5.42)$ & $(6.82)$ \\
\hline $\boldsymbol{R E} \boldsymbol{G}_{j t}$ & $-0.048 * *$ & $0.174 * *$ & & \\
\hline & $(0.014)$ & $(0.014)$ & & \\
\hline$R S E C_{j t}$ & & & $0.259 * *$ & $0.460 * *$ \\
\hline & & & $(0.054)$ & $(0.069)$ \\
\hline$R I N S_{j t}$ & & & -0.026 & $0.557 * *$ \\
\hline & & & $(0.042)$ & $(0.049)$ \\
\hline$R R E A L_{j t}$ & & & 0.030 & $0.467 * *$ \\
\hline & & & $(0.032)$ & $(0.038)$ \\
\hline$R_{N O N F I N}$ & & & $-0.321 * *$ & 0.048 \\
\hline & & & $(0.037)$ & $(0.066)$ \\
\hline Coefficients sp & & & & \\
\hline$\frac{a s}{\text { fixed: }}$ & & & & \\
\hline $\ln G D P_{j t}$ & $0.865 * *$ & & $0.809 * *$ & \\
\hline & $(0.032)$ & & $(0.032)$ & \\
\hline GDPgrowth $_{j t}$ & $-0.038 * *$ & & $-0.054 * *$ & \\
\hline & $(0.011)$ & & $(0.012)$ & \\
\hline $\operatorname{lnDIST} T_{j t}$ & $-0.734 * *$ & & $-0.723 * *$ & \\
\hline & $(0.050)$ & & $(0.050)$ & \\
\hline$C O M L A N G_{j t}$ & -0.124 & & -0.061 & \\
\hline & $(0.096)$ & & $(0.104)$ & \\
\hline CONTIG $_{j t}$ & $-0.335 * *$ & & $-0.397 * *$ & \\
\hline & $(0.075)$ & & $(0.080)$ & \\
\hline$D T T_{j t}$ & $0.008 * *$ & & $0.010 * *$ & \\
\hline & $(0.002)$ & & $(0.002)$ & \\
\hline$B I T_{j t}$ & $-0.012 * *$ & & $-0.014 * *$ & \\
\hline & $(0.001)$ & & $(0.001)$ & \\
\hline$B A N K S E C_{j}$ & $1.461 * *$ & & $1.516 * *$ & \\
\hline & $(0.101)$ & & $(0.110)$ & \\
\hline$N$ & 150,563 & & 150,563 & \\
\hline
\end{tabular}

Notes: Mixed logit estimates; 3,501 positive location choices. Random variables: STR is the statutory corporate tax rate of the subsidiary's host country. RATIO equals the minimum equity ratio required in the host country. REG is an indicator for restrictions in different activities. RSEC, RINS, RREAL and RNONFIN are components of REG. Fixed variables: lnGDP is host country GDP in logs, GDP growth indicates yearly growth in host country GDP. lnDIST is the distance between home country and host country in logs. COMLANG is a dummy variable indicating a common official language. CONTIG is a dummy variable for a common boarder. DTT and BIT equal the number of double tax treaties and bilateral investment treaties of the host country respectively. BANKSEC is a dummy variable indicating the existence of high bank secrecy in the host country. * and ** indicate significance at the $5 \%$ and $1 \%$ level. More information concerning control variables is provided in Table 6 in the Appendix. 


\subsection{Policy Experiments}

Based on the results in Table 1, we may estimate how countries are affected by a unilateral policy choice of the United States. For example, in a first experiment we estimate the losses measured in probability mass associated with a total abolishment of equity regulation in the US $\left(\right.$ RATIO $\left._{\mathrm{US}}=0\right)$. Figure 3 shows that the burden of such a policy is very unevenly distributed across countries facing the policy externality. While some countries are heavily affected, the effect on many countries is hardly measurable.

The estimates suggest that the biggest losers of the one-sided US policy action would be the UK (-0.08), France (-0.05), Luxembourg (-0.046), Belgium (-0.03), the Netherlands (-0.029), and Switzerland (-0.027). Ranking the countries according to their losses is broadly but not fully in line with estimated base probabilities. For example, in terms of its base probability, Canada is estimated as the country with the 15 th highest one. At the same time, the loss in probability mass associated with the hypothetical US policy is -0.0165463 and this implies rank 11. Given our estimation approach, this is consistent with what we would expect in context of policy spillovers: They are more likely to occur when countries are close to each other.

FIGURE 3: Distribution of Probability Losses when RATIO ${ }_{\text {US }}=0$

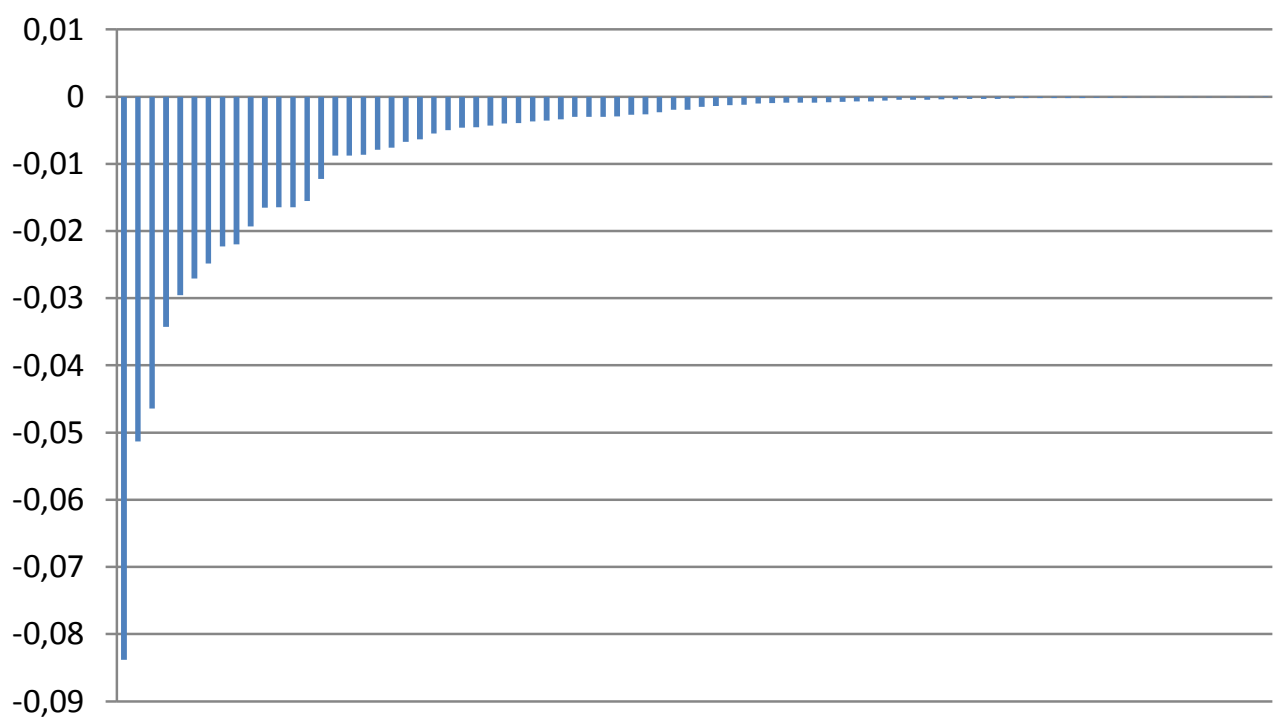


The second experiment is motivated by proposals to coordinate equity requirements and regulation. For this we simulate a coordinated policy action and set RATIO equal to 0.13 (13\% equity requirement is the new target ratio agreed on in Basel III for the year 2019). This experiment produces winners and losers. The losses (in parenthesis) of such a coordinated policy are often significant: Luxembourg (-0.017), Great Britain (-0.014), USA (-0.007), France (-0.006), Ireland (-0.006), Switzerland (-0.005). However, there are also winners. The countries benefiting most are Russia $(+0.025)$, Brazil $(+0.007)$, Bulgaria $(+0.006)$, Turkey $(+0.0057)$ and India (+0.0046). Figure 4 displays the distribution of gains and losses, with Luxembourg and Great Britain at the very left of the gain-and-loss distribution and Russia at the very right.

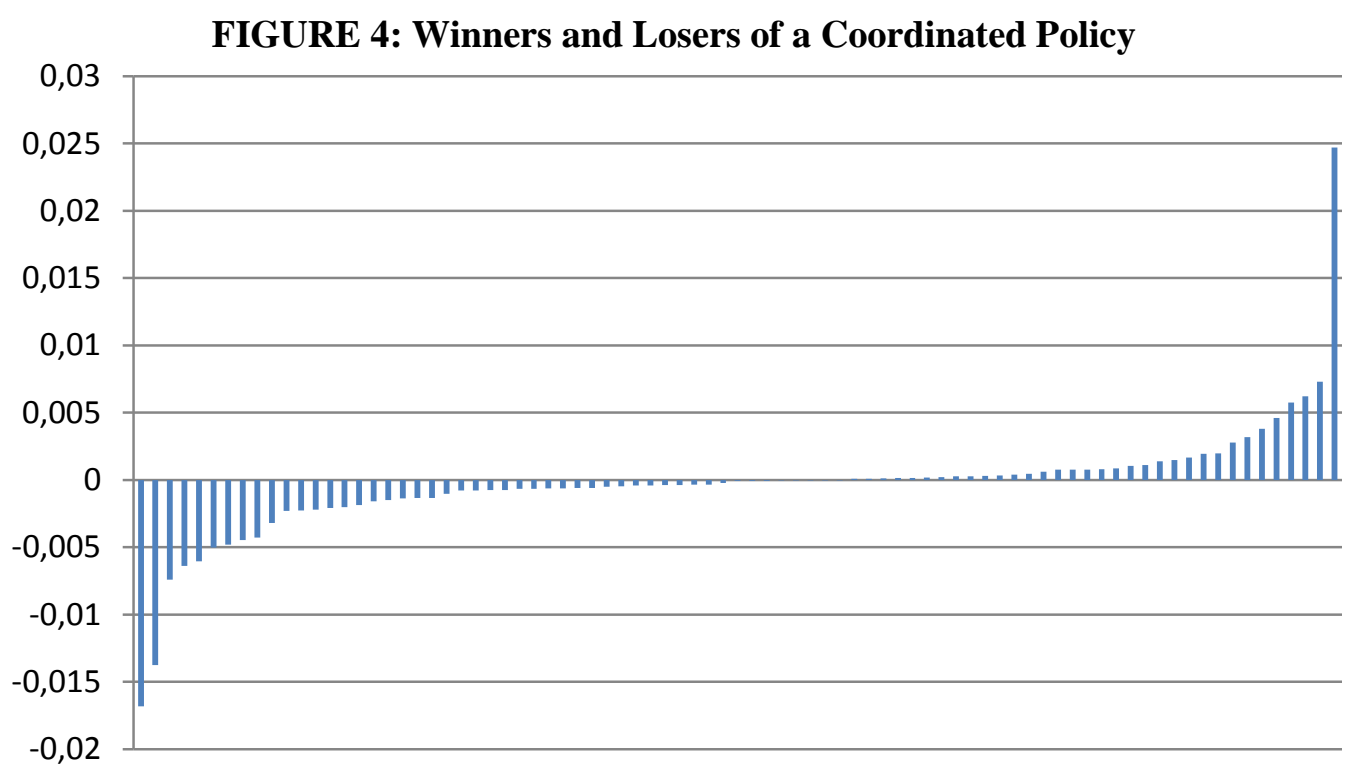

\section{Conclusion}

We have analyzed how the location of financial sector FDI is affected by taxes and the regulatory environment. For the empirical analysis, we have considered novel data, covering the universe of German outbound financial sector FDI over a time span of 13 years. Our results suggest that not only regulation but also tax incentives matter for the location of financial sector FDI. 
Our empirical approach also computes cross-elasticities for tax incentives and regulation. We find that a change in tax and regulation policy of one country affects the location probabilities of other countries. Another important finding of our analysis is that own- as well as crosselasticities are estimated to be highly heterogeneous across firms and countries. For example, expressed in elasticities, we find that US financial sector FDI is less responsive to tax and regulation policy compared to financial sector FDI in countries like Singapore or Hong Kong.

Our findings have interesting policy implications. First, given that recent discussions in the context of financial sector FDI often focus on regulation policy, our results suggest that policymakers may place more emphasis on tax policy. Second, our findings confirm the expectation that the responsiveness to tax and regulation policies varies across host countries. Third, the result of significant externalities arising from uncoordinated policies implies that coordinated action, particularly in regulation policy, is needed. 


\section{Appendix}

TABLE 6: Variable Description

\begin{tabular}{|c|c|c|}
\hline Variable & Definition & Source \\
\hline LOCDEC & $\begin{array}{l}\text { Dependent variable indicating location } \\
\text { decision }\end{array}$ & $\begin{array}{l}\text { Research Data and Service } \\
\text { Centre (RDSC) of the } \\
\text { Deutsche Bundesbank, } \\
\text { Microdatabase Direct } \\
\text { Investment (MiDi), 2000- } \\
2012 \text {, own calculations }\end{array}$ \\
\hline $\operatorname{lnGDP}$ & $\begin{array}{l}\text { Gross domestic product of host country } \\
\text { (in logs) }\end{array}$ & $\begin{array}{l}\text { World Bank: World } \\
\text { Development Indicators } \\
\text { (WDI) Database }\end{array}$ \\
\hline GDPgrowth & $\begin{array}{l}\text { Annual growth rate of gross domestic } \\
\text { product of host country }\end{array}$ & $\begin{array}{l}\text { World Bank: World } \\
\text { Development Indicators } \\
\text { (WDI) Database }\end{array}$ \\
\hline COMLANG & $\begin{array}{l}0-1 \text { dummy variable for the existence of } \\
\text { a common language }\end{array}$ & $\begin{array}{l}\text { Centre d'Études } \\
\text { prospecitves et } \\
\text { d'Informations } \\
\text { Internationales (CEPII) }\end{array}$ \\
\hline $\operatorname{lnDIST}$ & $\begin{array}{l}\text { Log of distance between home country } \\
\text { and host country }\end{array}$ & $\begin{array}{l}\text { Centre d'Études } \\
\text { prospecitves et } \\
\text { d'Informations } \\
\text { Internationales (CEPII) }\end{array}$ \\
\hline CONT & $\begin{array}{l}0-1 \text { dummy variable for the existence of } \\
\text { a common boarder }\end{array}$ & $\begin{array}{l}\text { Centre d'Études } \\
\text { prospecitves et } \\
\text { d'Informations } \\
\text { Internationales (CEPII) }\end{array}$ \\
\hline DTT & Number of double tax treaties & $\begin{array}{l}\text { United Nations Conference } \\
\text { on Trade and Development } \\
\text { (UNCTAD) }\end{array}$ \\
\hline $\mathrm{BIT}$ & Number of bilateral investment treaties & $\begin{array}{l}\text { United Nations Conference } \\
\text { on Trade and Development } \\
\text { (UNCTAD) }\end{array}$ \\
\hline BANKSEC & $\begin{array}{l}0-1 \text { dummy variable for the existence of } \\
\text { high bank secrecy }\end{array}$ & OECD (2006) \\
\hline STR & Statutory tax rate & $\begin{array}{l}\text { International Bureau of } \\
\text { Fiscal Documentation, } \\
\text { IBFD; tax survey provided } \\
\text { by Ernst\&Young, PwC and } \\
\text { KPMG }\end{array}$ \\
\hline RATIO & Minimum equity required in host country & Barth et al. (2001) \\
\hline RSEC & $\begin{array}{l}\text { Indicator on conditions to engage in } \\
\text { securities activities }\end{array}$ & Barth et al. (2001) \\
\hline RINS & $\begin{array}{l}\text { Indicator on conditions to engage in } \\
\text { insurance activities }\end{array}$ & Barth et al. (2001) \\
\hline RREAL & $\begin{array}{l}\text { Indicator on conditions to engage in real } \\
\text { estate activities }\end{array}$ & Barth et al. (2001) \\
\hline RNONFIN & $\begin{array}{l}\text { Indicator on conditions to engage in non- } \\
\text { financial activites }\end{array}$ & Barth et al. (2001) \\
\hline REG & $\begin{array}{l}\text { Combined indicator on conditions to } \\
\text { engage in securities, insurance, real } \\
\text { estate, non-financials }\end{array}$ & Barth et al. (2001) \\
\hline
\end{tabular}


TABLE 7: Descriptive Statistics

\begin{tabular}{lcc}
\hline Variable & Mean & Standard Deviation \\
\hline LOCDEC & 0.012 & 0.110 \\
lnGDP & 25.781 & 1.717 \\
GDPgrowth & 3.919 & 3.769 \\
COMLANG & 0.049 & 0.216 \\
lnDIST & 8.123 & 1.121 \\
CONT & 0.098 & 0.297 \\
DTT & 43.911 & 32.651 \\
BIT & 39.747 & 27.185 \\
BANKSEC & 0.259 & 0.438 \\
STR & 0.266 & 0.094 \\
RATIO & 0.091 & 0.017 \\
RSEC & 1.660 & 0.797 \\
RINS & 2.476 & 0.979 \\
RREAL & 2.634 & 1.291 \\
RNONFIN & 2.394 & 1.001 \\
REG & 9.164 & 3.115 \\
\hline
\end{tabular}

Notes: Descriptive statistics of variables used in the empirical analysis. Number of observations is 309,912 observations ( $\left({ }^{\text {a) }} 160,628\right.$ observations). LOCDEC considers location decisions of financial services entities. Source: Research Data and Service Centre (RDSC) of the Deutsche Bundesbank, Microdatabase Direct Investment (MiDi), 2000-2012, own calculations. lnGDP is host country GDP in logs, GDP growth indicates yearly growth in host country GDP. COMLANG is a dummy variable indicating a common official language. lnDIST is the distance between home country and host country in logs. CONTIG is a dummy variable for a common boarder. DTT and BIT equal the number of double tax treaties and bilateral investment treaties of the host country respectively. BANKSEC is a dummy variable indicating the existence of high bank secrecy in the host country. STR is the statutory corporate tax rate of the subsidiary's host country. RATIO equals the minimum equity ratio required in the host country. REG is an indicator for restrictions in different activities. RSEC, RINS, RREAL and RNONFIN are components of REG. 
TABLE 8: Location Decisions

\begin{tabular}{ll}
\hline Country & Number of location decisions \\
\hline USA & 760 \\
GB & 524 \\
NL & 251 \\
LUX & 239 \\
I,F, PL, CH,AT, CAY & $>100$ \\
Singapore, Canada, RUS, IRL, B, SP & $>50$ \\
Malta/Hong Kong/Singapore & $>40$ \\
Cyprus & 10 \\
\hline
\end{tabular}

Source: Research Data and Service Centre (RDSC) of the Deutsche Bundesbank, Microdatabase Direct Investment (MiDi), 2000-2012, own calculations. 


\section{References}

Admati, A.R., DeMarzo, P.M., Hellwig, M.F. and Pfleiderer, P. (2010) Fallacies, Irrelevant Facts, and Myths in the Discussion of Capital Regulation: Why Bank Equity is Not Expensive, Stanford Graduate School of Business Research Paper, No. 2065, Stanford University.

Barrios, S., Huizinga, H., Laeven, L. and Nicodème, G. (2012). International Taxation and Multinational Firm Location Decisions, Journal of Public Economics 96, 946-958.

Barth, J.R., Caprio Jr., G. and Levine, R. (2001). The Regulation and Supervision of Banks around the World: A New Database, Policy Research Working Paper 2588.

Berger, A.N., Buch, C.M., DeLong, G. and DeYoung, R. (2004). Exporting Financial Institutions Management via Foreign Direct Investment Mergers and Acquisitions, Journal of International Money and Finance 23, 333-366.

Bertus, M., Jahera Jr., J.S. and Yost, K. (2008). A Note on Foreign Bank Ownership and Monitoring: An International Comparison, Journal of Banking \& Finance 32, 338-345.

Buch, C.M. (2000). Information or Regulation: What Is Driving the International Activities of Commercial Banks?, Kiel Working Paper No. 1011.

Buch, C.M. (2003). Information or Regulation: What Drives the International Activities of Commercial Banks?, Journal of Money, Credit, and Banking 35, 851-869.

Buch, C.M. and DeLong, G. (2004). Cross-border Bank Mergers: What Lures the Rare Animal?, Journal of Banking \& Finance 28, 2077-2102.

Buch, C.M. and Lipponer, A. (2007). FDI versus Exports: Evidence from German Banks, Journal of Banking \& Finance 31, 805-826.

Buch, C.M., Neugebauer, K. and Schröder, C. (2013). Changing Forces of Gravity: How the Crisis Affected International Banking, Deutsche Bundesbank Discussion Paper No 48/2013.

Buch, C.M., Koch, C.T. and Koetter, M. (2014). Should I stay or should I go? Bank Productivity and Internationalization Decisions, Journal of Banking \& Finance 42, 266282.

Buettner, T. and Ruf, M. (2007). Tax Incentives and the Location of FDI: Evidence from a Panel of German Multinationals, International Tax and Public Finance 14(2), 151-164. 
Buettner, T. and Wamser, G. (2009). The Impact of Non-Profit Taxes on Foreign Direct Investment: Evidence from German Multinationals, International Tax and Public Finance 16, 298-320.

Brealey, R.A. and Kaplanis, E.C. (1996). The Determination of Foreign Banking Location, Journal of International Money and Finance 15, 577-597.

Cerrutti, E., Dell'Ariccia, G. and Martínez Pería, M.S. (2007). How Banks Go Abroad: Branches or Subsidiaries?, Journal of Banking \& Finance 31, 1669-1692.

Cetorelli, N. and Goldberg, L.S. (2009). Globalized Banks: Lending to Emerging Markets in the Crisis, Federal Reserve Bank of New York Staff Reports no. 377.

Cetorelli, N. and Goldberg, L.S. (2011). Global Banks and International Shock Transmission: Evidence from the Crisis, IMF Economic Review 59(1), 41-76.

Claessens, S., Demirgüç-Kunt, A. and Huizinga, H. (2001). How Does Foreign Bank Entry Affect Domestic Banking Markets?, Journal of Banking \& Finance 25, 891-911.

Claessens, S. and Van Horen, N. (2012). Foreign Banks: Trends, Impact and Financial Stability, IMF Working Paper 12/10.

Claessens, S. and Van Horen, N. (2014). Location Decisions of Foreign Banks and Competitor Remoteness, Journal of Money, Credit and Banking 46(1), 145-170.

Clarke, G., Cull, R., Martinez Peria, M.S. and Sánchez, S.M. (2003). Foreign Bank Entry: Experience, Implications for Developing Economies, and Agenda for Further Research, The World Bank Research Observer 18(1), 25-59.

De Mooij, R. and Everdeen, S. (2003). Taxation and Foreign Direct Investment: A Synthesis of Empirical Research, International Tax and Public Finance, 10(6), 673 - 693.

De Mooij, R. and Everdeen, S. (2006). What a Difference Does it Make? Understanding the Empirical Literature on Taxation and International Capital Flows, European Economy Economic Papers 261, DG ECFIN, European Commission.

Devereux, M.P. and Griffith, R. (1998). Taxes and the Location of Production: Evidence from a Panel of US Multinationals, Journal of Public Economics 68, 335-367.

Devereux, M.P., Johannesen, N. and Vella, J. (2013). Can Taxes Tame the Banks? Evidence from European Bank Levies, Working paper series 13/25. 
Devereux, M. (2014). New Bank Taxes: Why and What Will Be the Effect, in R. de Mooij and G. Nicodème (eds), Taxation and Regulation of the Financial Sector,25- 54.

Egger, P. and Merlo, V. (2012). BITs Bite: An Anatomy of the Impact of Bilateral Investment Treaties on Multinational Firms, The Scandinavian Journal of Economics 114(4), 12401266.

Egger, P., Fahn, M., Merlo, V. and Wamser, G. (2014a). On the Genesis of Multinational Foreign Affiliate Networks, European Economic Review 65, 136-163.

Egger, P., Merlo, V. and Wamser, G. (2014b). Unobserved Tax Avoidance and the Tax Elasticity of FDI, Journal of Economic Behavior \& Organization 108, 1-18.

Feld, L. and Heckemeyer, J. (2011). FDI and Taxation: A Meta-Study, Journal of Economic Surveys 25, 233-272.

Focarelli, D. and Pozzolo, A.F. (2001). The Patterns of Cross-Border Bank Mergers and Shareholdings in OECD Countries, Journal of Banking \& Finance 25, 2305-2337.

Focarelli, D. and Pozzolo, A.F. (2005). Where Do Banks Expand Abroad? An Empirical Analysis, Journal of Business 78(6), 2435-2463.

Grubert, H. and Mutti, J. (2004). Empirical Asymmetries in Foreign Direct Investment and Taxation, Journal of International Economics 62, 337 - 358.

Harr, T. and Ronde, T. (2005). Branch or Subsidiary? Capital Regulation of Multinational Banks, Working Paper.

Hart, O. and Zingales, L. (2011). A New Capital Regulation for Large Financial Institutions, American Law and Economics Review 13(2), 453-490.

Hovakimian, A. and Kane, E.J. (2000). Effectiveness of Capital Regulation at U.S. Commercial Banks, 1985 to 1994, The Journal of Finance 55, 451-468.

Huizinga, H.P., Voget, J. and Wagner, W.B. (2014). International Taxation and Cross-Border Banking, American Economic Journal: Economic Policy 6(2), 94-125.

Keeley, M.C. (1990). Deposit Insurance, Risk, and Market Power in Banking, The American Economic Review 80(5), 1183-1200.

Keen, M. (2011). The Taxation and Regulation of Banks, IMF Working Paper 11/206.

Lehner, M. (2009). Entry Mode Choice of Multinational Banks, Journal of Banking \& Finance 33, 1781-1792. 
Liberti, J.M. and Mian, A.R. (2009). Estimating the Effect of Hierarchies on Information Use, The Review of Financial Studies 22(10), 4057-4090.

McFadden, D. (1974). Conditional Logit Analysis of Qualitative Choice Behavior in: P. Zarembka (ed.), Frontiers in Econometrics, Academic Press, New York, 105-142.

OECD (2006). Tax Co-operation: Towards a Level Playing Field, OECD Publishing.

OECD (2013). Action Plan on Base Erosion and Profit Shifting, OECD Publishing.

Overesch, M. and Wamser, G. (2009). Who Cares About Corporate Taxation? Asymmetric Tax Effects on Outbound FDI, The World Economy 32, 1657-1684.

Petersen, M.A. and Rajan, R.G. (2002). Does Distance Still Matter? The Information Revolution in Small Business Lending, The Journal of Finance 57(6), 2533-2570.

Popov, A. and Udell, G.F. (2012). Cross-Border Banking, Credit Access, and the Financial Crisis, Journal of International Economics 87, 147-161.

Rajan, R.G. (1992). Insiders and Outsiders: The Choice between Informed and Arm's-length Debt, Journal of Finance 47, 1367-1400.

Temesvary, J. (2014a). The Determinants of U.S. Banks' International Activities, Journal of Banking \& Finance 44, 233-247.

Temesvary, J. (2014b). Foreign activities of U.S. Banks since 1997: The Roles of Regulation and Market Conditions in Crises and Normal Times, Journal of International Money and Finance, 1-24.

Train, K.E. (2009). Discrete Choice Methods with Simulation, Second Edition, Cambridge University Press, New York.

Tsai, H., Chang, Y. and Hsiao, P. (2011). What Drives Foreign Expansion of the Top 100 Multinational Banks? The Role of the Credit Reporting System, Journal of Banking \& Finance 35, 588-605.

Weitzman, M. (1974). Prices vs. Quantities, Review of Economic Studies 41, 477-491.

Yamori, N. (1998). A Note on the Location Choice of Multinational Banks: The Case of Japanese Financial Institutions, Journal of Banking \& Finance 22, 109-120. 